\title{
INTEREST-F REE BANKING'S AND CONVENTIONAL BANKING'S ATTITUDES AGAINST FINANCIAL CRISES: THE CASE OF TURKEY ${ }^{1}$
}

\author{
MustafaCANBAZ ${ }^{2}$ \\ Emre CEVIK ${ }^{3}$
}

Başvuru Tarihi: 01.03.2015

Kabul Tarihi: 17.03.2015

\begin{abstract}
Following the financial crisis in 2001, Turkish banking sector started a 'restructuring' process. This led to a recovery of the damage caused by the crisis and, despite the significant decrease in the number of the banks, the banking sector gained quite a sound structure. This improvement allowed it to remain strong against the global financial crisis that took place after 2007 and caused important progress for many financial indicators, in particular the deposits andloans.

Interest- free banking, which has been operating in form of participation bank through the profit and loss sharing system since 2005, become a competitor, in a different aspect, to deposit banks, an important part of the conventional banking. This study compares attitudes of the Participation Banks and the Deposit Banks against their customers before and after the crisis, in light of the financial indicators from the financial statements. The analysis concludes that Particpiation Banksa re significantly different from Deposit Bank in aspect of activity ratios', which are based on the main areas of activity.
\end{abstract}

Key Words: participation banking, deposit banking, t-test, Welch test, financial indicators

JEL Code: $\mathrm{C} 12, \mathrm{G} 21$

\footnotetext{
${ }^{1}$ The present paper was summarized from the statement presented in the $2^{\text {nd }}$ International Conference on Islamic Economics and Economies of the OIC Countries - 2013 Conference held in Kuala Lumpur, Malaysia on 29

- 30 January 2013.

${ }^{2}$ Assist. Prof. Dr., Bezmialem Vakıf University, Department of Health Management, Faculty of Health Sciences, Bezmialem Vakıf University, İstanbul, Turkey.

Corresponding Author. Tel: +90 (212) 52322 88, Fax: +90 (212) 621 75 78, E---mail: mcanbaz67@yahoo.com

${ }^{3}$ Asis. Krrklareli University, Department of Econometrics, FEAS, Kirklareli University, Kavakli, Kirklareli, Turkey, cevik.emre@gmail.com
} 


\section{FAİZSIZ VE KONVANSIYYNEL BANKACILIĞIN KRIZZLER KARŞISINDA MÜŞTERIYE KARŞI DAVRANIŞLARININ FINANSAL GÖSTERGELER ÜZERINDEN ANALIZİ: TÜRKIYYE ÖRNEGİ}

\section{ÖZ}

2001 yılında kendine özgü nedenlerle büyük bir 'finansal kriz' yaşadıktan sonra, Türk Bankacllk Sektörü, 'yeniden yapılanma' sürecine girmiştir. On yılın sonunda önemli gelişme göstererek hem içerde ve hem de dışarıda daha çok rekabetçi bir niteliğe kavuşmuştur. Sistemin bir parçası olan 'faizsiz bankacılık' ise, henüz otuz yillık geçmişine ră̆men bu dönemi hem kurumsallaşma ve hem de gelişen ülke ekonomisinin en dinamik kesimi olan küçük ve orta boy işletmelere yaptığ finansman desteğ i ile dikkat çekmiştir.

Krizin bankacılık sektöründe meydana getirdiği hasar, son on yıllık süreçte giderilmiştir. Banka saylsı büyük azalma yaşamış, buna rağmen, oldukça sağlıklı bir mali yapıya kavuşmuştur. Bu gelişme, 2007 sonrasında ortaya çıkan küresel finans krizi karşısında güçlü kalmasını sağlamış ve başta varlıklar, krediler, fonlar ile özkaynaklar olmak üzere birçok finansal göstergede önemli gelişme yaşanmıştır. Bu arada, finans ve bankacılık sistemin bir parçası olarak 1983 yılında, 'özel finans kurumu’ olarak faaliyete başlayan faizsiz bankalar ise, dönemin sonlarında 'Katılım Bankası'na dönüşmüştür. 'Kar-zarar ortaklı̆̆ı esası' ile bankacllk yapan bu kurumlar, dönem boyunca gösterdikleri daha yüksek performansla bir yandan Türk Bankacllk Sektörü'nün önemli bir parçası haline gelirken, diğer yandan konvansiyonel bankacılı̆̆a rakip olacak işaretler göstermiştir. Bu rekabetin temel göstergeleri, bankacılı̆̆ın esas faaliyet konusu olan fon toplama ve kullandırma' fonksiyonunun mali tablolara yansiyan kalemlere ait tutarlardır. Bu finansal göstergelerin, kriz öncesi ve sonrası eğilim ve farklılıklarının iki banka türü açısından belirlenmesi ve ortaya çıkarılması, hem rekabet hem de temel bankacılık anlayışfarkının ortaya konulması açısından hem zaruri hem de önemlidir.

Bu çalışmada, mali tablolardan elde edilen finansal göstergelerle 2008 kriz öncesi ve kriz sonrasında Katılım ve Konvansiyonel Bankacılı̆ğ ’n önemli parçası olan Mevduat Bankaları'nın müşterilere karşı tutumları üzerinden karşılaştırılması yapılarak, farklılıklar belirlenmeye çalışılmıştır. Analiz sonucunda, Katılım Bankaları'nın Mevduat Bankaları'ndan özellikle, 'esas faaliyet konuları'nı içeren 'etkinlik rasyoları' açısından önemli farklılıklar gösterdiğitespitedilmiştir.

Anahtar Kelimeler; faizsiz ve katılım bankacılığı, konvansiyonel bankacıllk, t testi, Welch testi, finansal göstergeler

JEL Kodlar: C12, G21

\section{Introduction}

'Interest-free banking', or Participation Banks with a more current name, that started under the name of 'Special Finance Houses' globally in the 1970s, and in 1983 in Turkey under the driving force of foreign capital have been gradually increasing their importance and share in the Turkish Banking System (TBS). Collecting the funds in a partially similar way with conventional banking, yet utilizing these in line with the 'interest-free financing' principles, Participation Banks share the incurred loss or profit with the saving holders on the basis of a pre-determined rate. In this way, while functioning as supplementaries to the conventional interest-based banks by means of introducing the idle funds kept away from banks due to savers' beliefs on 'interest prohibition', they also contribute to the development of an 
alternative market through financial instruments not offered by conventional banks (Ece, 2011). On the other hand, they bring in diversity and depth to financial markets. However, the requirement of 'involving a real/true and legitimate activity', a basic principle of the 'interestfree financing' banks, has a significant and beyond-calculable multiplier effect throughout the economy. Because 'real and legitimate operations' are transactions that contribute to the society and correspond to human needs, the limits of which are determined as either lawful or unlawful according to Islam.

In a sense, banking constitutes lifeline by means of the source/funds it provides to economies. However, occasionally it may be also the source of financial difficulties and crisis as it is today. In the last quarter century, conventional banking has made a great progress and gained remarkable ground all around the world with the high speed provided by technology. In addition, straying off of traditional products and services, conventional banks got to be known with their leading role in exporting or trading illiquid assets in capital markets, converting them into securities (securitization) through very different and diverse new derivative products. Due to this reason, the last quarter of a century was presented as the 'shining period' for banking and modern finance (Dogru, 2007).

However, a common understanding exists among nearly every industry, on the 'new products' presented as a success by banking and the 'modern finance' being the main cause of the ongoing global financial crisis (Alantar, 2008; Afsar, 2011). It is rather difficult to scientifically explain such a economic and 'financial/monetary system' that omits production and solely based on paper being healthy. As a matter of fact, it receives intense criticis $\mathrm{m}^{4}$.

\footnotetext{
${ }^{4}$ It may be useful to review some of the related studies presented below;

- Mete GUNDOGAN; Borca Dayalı Para Sistemi Türkiye'nin Sosyo---Ekonomik Analizi, http://metegundogan.com/wp---content/uploads/2011/08/BDPS---MeteGundogan.pdf, Accessed on: $15 / 04 / 2012$

- $\quad$ Mete GUNDOGAN; Faiz Tuzağı, Keşif Publications, Ankara 2002

- Gültekin CETINER; "O Adada Siz Olsaydınız?", http://drcetiner.org/ekonomi/o---adada---sizolsaydiniz.html, Accessed on: 15/04/2012

- Gültekin CETINER; "Cari açık ve yastık altındaki altınlar", http://drcetiner.org/ekonomi/cari---acik---veyastik---altindaki---altinlar.html, Accessed on: 05/05/2012

- OZKAN, F.G. (2008), "Finansal İstikrar ve Makroekonomik Etkileşim”, BDDK 8. Kuruluş Yıldönümü Konferansı, Küresel ve Ulusal Finansal Sistemde Yeni Mimari Arayışları, Konuşmalar Makaleler Kitabı, 29 August, Istanbul, s.71--85

- Maher HASAN and Jemma DRIDI; The Effects of the Global Crisis on Islamic and Conventional Banks: A Comparative Study, IMF Working Paper, September 2010,

- Miranti Kartika DEWi; Islamic Finance: A Therapy for Healing the Global Financial Crisis, http://cgfs.hu.edu.jo/confernce\%20papers/Miranti\%20Kartika\%20Dewi\%20/\%20Islamic\%20Finance \%20A\%20Therapy\%20for\%20Healing\%20the\%20Global\%20Fin\%20Crisis).pdf, Accessed on: $20 / 02 / 2012$
} 
The increase in derivative financial instruments in the USA, banks risking the saving holders' money for growing their assets and profits, and the fact the such accumulated risks hold important place in the balance sheets of European banks caused the crisis to spread to the whole system. In the meantime, the dazzling growth from 2000 to 2008 and concealment of the causes that dragged banking into the crisis (Yildiran, 2011) further contributed to the spreading impact of the crisis. In the end, the crisis that originated from the decrease in real estate prices in the USA and the losses from the repayment of mortgage credits, known as housing credits, spread to the global scale and grew both in effect and severity (AbdulRahman, 2010).

Leaving aside the impact of the crisis, which is now known to be caused by conventional banking and the effects of which still continue, on the financial markets, even the magnitude of the damage it caused on the world merchandise trade would be sufficient to exhibit the severity of the losses. According to the 2010 Report of the World Trade Organization, the damage world merchandise trade suffered is as follows (http//www.wto.org/english/news_e/pres11_e/pr628_e.pdf, Accessed on: 15/05/2012);

- In 2009, world merchandise trade shrunk by $22,8 \%$ in value. This corresponds to an approximate amount of 3,5 Trillion US\$.

- In connection with this shrinkage, the 15,7 Trillion \$ merchandise trade of 2008 decreased to 12,2 Trillion $\$$ in 2009 , and with the $10 \%$ increase in 2010 , it reached back $15,2 \%$ and once again got close to the level of 2008 .

In consequence of the crisis, the damages of which were mostly evident in the USA and Europe, a series of regulations, particularly concerning the contraction in derivative products, stricter supervision and controlling of the banking system, were brought to the agenda and implemented. On the other hand, the attention interest-free banks which conduct banking on the basis of different principles, rules and products attract increased and in many developed countries that host Muslim minorities organizations that carry out 'interest-free banking'

\footnotetext{
Abul HASSAN, "The Global Financial Crisis and Islamic Banking", http://www.islamic--foundation.org.uk/IslamicEconomicsPDF/Hassan---financialcrisis--if.pdf, Accessed on: 15/02/2012

- Soros, George; The New Paradigm For Financial Markets, The Credit Crisis of 2008 and What It Means, BBS Public Affairs, New York, 2008

....; Faith and the Global Agenda: Values for the Post---Crisis Economy, 2010 World Economic Forum, https://members.weforum.org/pdf/faith/valuesreport.pdf, Accessed on: 20/10/2011 ...; Issues in the International Financial Crisis from an Islamic Perspective, Prepared by: Group of Researchers, Islamic Economic Research Center, King Abdulaziz University, Jeddah, 2009
} 
emerged. Their number has reached 1000 in 75 countries (http $/ /$ www.inceif.org/index.php/ind ustry-composition?tmpl, Accessed on: 05/05/2012).

The present study addresses the differences between Deposit Banks among the conventional banks in the Turkish Banking System, and the 'Participation Banks' as the equivalent of 'Interest-free Banks' in Turkey, which are oriented on providing finance through real economic activities and that draw attention all around the world with their durability against crises. These differences were examined through a statistical analysis in consideration of the financial indicators derived from financial statements and on the basis of the banks' attitudes towards their customers.

\section{Conventional Banking in Turkey}

In this section, brief information on the development of conventional banking in Turkey will be provided. Also known as 'traditional banking', conventional banking initially entered Turkey in the second half of the 19th Century as a remedy for the borrowing need of the state. Banking did not emerge to fulfill the need of the society, but the need of the state. In this period, borrowing from the domestic and foreign markets became even more essential for the Ottoman Empire particularly to finance the wars the state involved in (the last one being the Crimean War). On the other hand, the Muslim Ottoman Society mostly involved in civil services or handicrafts usually provided for their financial problems through traditional methods (such as families borrowing from their relatives) and avoided professions that carry out activities similar to banking such as money changing, brokerage and usury. However, ever since Sultan Mehmet's conquest of Istanbul, non-Muslim minorities such as the Jews, Armenians and Greeks continued to give loans with interest also in the Ottoman state, as they had been doing in Rome ever since the Middle Age. Since those involved in this activity were mostly in the Galata and Pera (Beyoglu) districts of the city, they have been known as the 'Brokers of Galata' ever since the 18th Century. In addition to lending to the state or brokerage, they also followed the businesses of the large European firms and merchants in Istanbul. The district that became not only a spot where the brokerage or banking activities concentrate on, but also a center of entertainment and shopping quite open to the Western lifestyle of Istanbul towards the final quarter of the 19th Century, maintained its commercial and financial significance until the 2000s, particularly with the banks, business and trade centers located in the Street of Banks. 
The first effort to establish a bank in the Ottoman state was made in 1847 by the money changers and brokers known as 'Galata Brokers'. However, due to the difficulties it had in payment and speculations, this bank (Istanbul Bank) did not last for long and was terminated in 1852. Ottoman Bank established later on in 1856, in London with British capital was registered as the first modern trade and credit bank(Coşkun, M.N. et al., 2012). This bank could live until the end of the 20th Century and was liquidated before seeing the 2000s. After this, many banks with mainly foreign origins were established; yet the interest of Muslims and Turks could only be seen at early 20th Century. In time, this interest increased so much that towards the end of the century, almost every holding decided to own a bank and therefore this period became known as the 'holding banking' period. However, the financial crises experienced one after the other in 1999 and the early 2000s marked the end of 'holding banking' and most of these got liquidated. Today, for more than a decade Turkish Banking System has been developing on a healthy platform despite the global financial crisis and has become one of the most important, and even the most essential part of the financial system.

Turkish Banking System, the assets size of which was 170,8 Million TL in early 1990, could only reach a magnitude of 216,6 Million TL in twelve years (in 2002) with an increase of 27\%, while at the end of 2012 it reached 1,37 Trillion TL by growing 5.3 times (BDDK, Türk Bankacilk Sektörü Genel Görünümü-Aralık 2012, 2013). In its current state, TBS constitutes more than $80 \%$ of the financial system consisting of banks and insurance companies. Growing at a high speed, the size of the banking system corresponds to almost the entire Gross National Product (GNP).

In this robust growth TBS exhibited in the last twelve years, rectification of the damages on the system due to the 1999 - 2001 crisis and reconstruction in line with the objective of building a strong basis by disposing off weak banks have been effective. On the other hand, the strong performance exhibited by the TBS in the face of the crisis that broke out in 2008 and the effects of which still continues at global scale was closely followed by all developed countries and accepted as a model.

With 49 banks and approximately 200 thousand personnel at the end of the year 2012, TBS is a dynamic and rapidly growing sector (Banking Regulation and Supervision Agency, 2011). In addition, by means of the 'alternative distribution channels', each of which doing business at branch level, it has an important role in keeping the record of the economy. The change and transformation witnessed in banking is not qualitative anymore and has gained also a quantitative characteristic. In the last decade, the partnership and capital structures of many 
banks that attract the attention of the foreign capital were changed, a substantial amount of foreign funds entered to the economy and became the sector with the most intense foreign capital. In addition to product and service diversity, changes were also experienced in customer relations and funding, and bank incomes shifted from 'interest incomes' to 'non- interest incomes'. Eventually, the changed continued with the assignation of the supervision and control of the sector to the Banking Regulation and Supervision Agency (BRSA) established in 1999 for the purpose of having these tasks carried out by a single authority.

Table 1: Banks Operating in Turkey and Their Numbers (2014)

\begin{tabular}{|c|l|}
\hline Bank Type & Number \\
\hline 1- Banks of Deposit & 32 \\
\hline 2- Development and Investment Banks & 13 \\
\hline 3- Participation Banks & 4 \\
\hline Total & $\mathbf{4 9}$ \\
\hline
\end{tabular}

Source:http://www.bddk.org.tr/WebSitesi/turkce/Raporlar/TBSGG/13131tbs_genel_gorunum u_2014.pdf Accessed on: 12/07/2015

The present study covers 29 conventional banks having the authority to 'collect deposit' as the primary functions of banks and 4 participation banks. What these two different types of bank have common is the authority to collect funds/deposit from the market and to offer these almost to the same market as credit. Accordingly, they keep in contact with the same clients both when they collect funds and when they make them available. In this aspect, the attitudes and sensitivities banks show to the market and their clients give researchers a serious idea in terms of the primary strategies banks follow. Although the banks included in the scope of the study constitute $69 \%$ of all banks in the system, in terms of assets they hold $97 \%$ of the total assets in the system. On the other hand, while the conventional banks included in the scope represent more than $90 \%$ of the banks of the same type in the system, all of the Participation Banks were included in the scope of the study. Accordingly, the banks included in the scope represent almost the entire banking sector in Turkey.

The 216,6 Million TL worth of total assets corresponding to 53 banks at the end of 2002, the beginning of the analysis, reached 1.370,6 Billion TL by the end of 2012. Similarly, within 
the same period also equities exhibited an increase in parallel with the assets and increased from 25,7 Billion TL to 181,8 Billion TL. Thus, balance sheet of TBS grew by 6.3 times from 2002 to 2012. On the other hand, while 'Deposits' grew by 5.3 times, 'Credits' scored an astonishing 14.5 times growth and 'Equities' grew by 7.1 times.

Table 2: Turkish Banking System(TBS) Balance Sheet Structure (in Billion TL)*

\begin{tabular}{|l|l|l|l|c|}
\hline Years & \multicolumn{1}{|l|}{ Assets } & Deposit & Credit & Equities \\
\hline 2002 & 216.637 .0 & 145.594 .0 & 54.860 .0 & 25.7 \\
\hline 2003 & 254.863 .0 & 164.923 .0 & 72.169 .0 & 35.5 \\
\hline 2004 & 313.751 .0 & 203.385 .0 & 107.615 .0 & 46.0 \\
\hline 2005 & 406.915 .0 & 261.948 .0 & 160.005 .0 & 54.7 \\
\hline 2006 & 498.587 .0 & 324.069 .0 & 228.141 .0 & 59.5 \\
\hline 2007 & 580.607 .0 & 371.927 .0 & 293.928 .0 & 75.8 \\
\hline 2008 & 731.640 .0 & 472.695 .0 & 384.417 .0 & 86.4 \\
\hline 2009 & 833.968 .0 & 522.415 .0 & 418.684 .0 & 110.9 \\
\hline 2010 & 1.006 .672 .0 & 631.119 .0 & 554.128 .0 & 134.5 \\
\hline 2011 & 1.217 .695 .0 & 695.501 .0 & 682.900 .0 & 144.6 \\
\hline 2012 & 1.370 .614 .0 & 771.884 .0 & 794.756 .0 & 181.8 \\
\hline & & & & \\
\hline
\end{tabular}

Source: http://www.bddk.org.tr, Accessed on: 15/01/2013

* In December 2012, 1 US\$ was equivalent to $1,80 \mathrm{TL}$ in average.

The asset size of the deposit banks in the TBS was 1.118,9 Billion TL at 2011 end and constituted $92 \%$ of the total assets of banking. On the other hand, the shares of Participation Banks and Development Banks were 5\% and 3\% respectively. However, the average distribution of these total assets highly differentiates in terms of banks. While the total assets of Deposit Banks were 37.3 Billion TL per bank, the total assets per bank for Development banks were 4.3 Billion TL and that for Participation Banks were 10.4 Billion TL. 


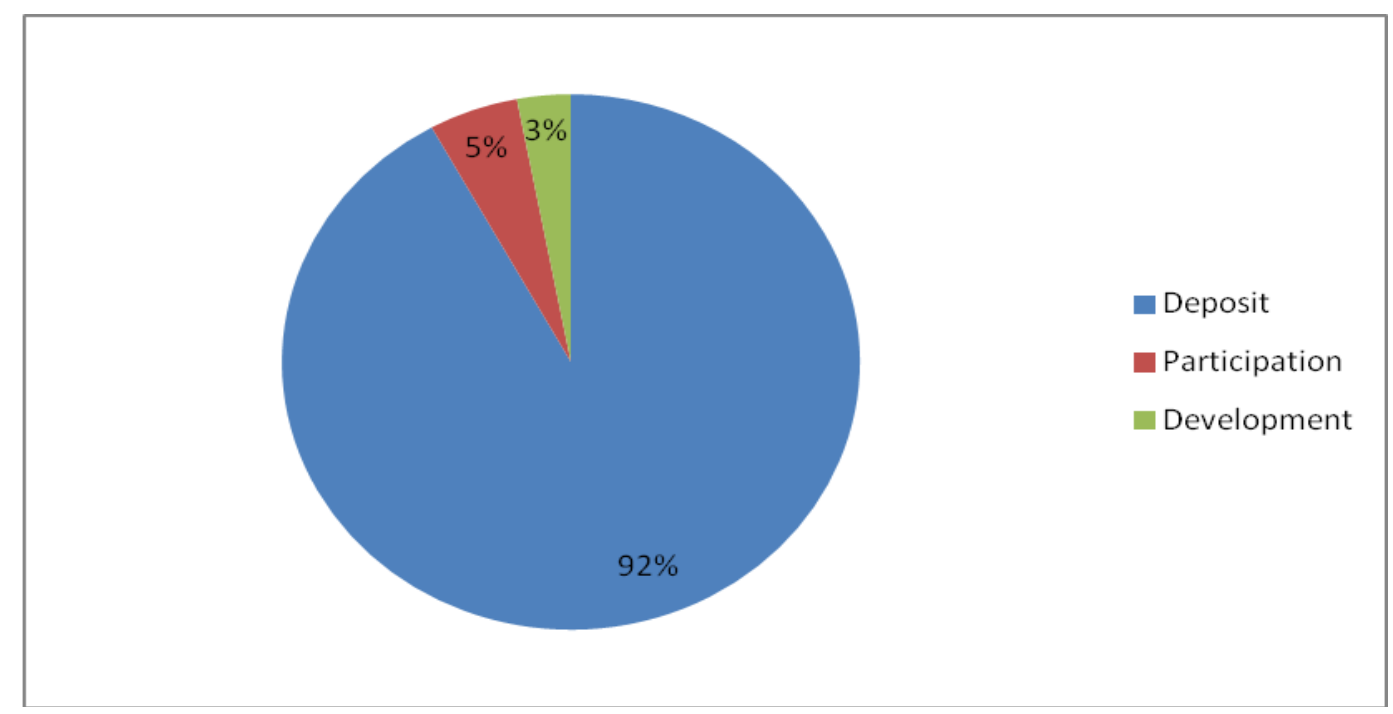

Figure 1. Total Assets Distribution in Terms of Bank Types

\section{Participation Banking in Turkey}

\subsection{Participation Banking in General}

The activities of Participation Banking, which is also known as 'interest-free banking' or 'Islamic banking' in the literature, are included within the banking practice that started as Special Finance Houses with the transition from the closed economic system to the outwardoriented model that took place after 1960 in the world and after 1980 in Turkey.

In the study conducted by Dogan (2008) the reasons for the emergence of interest-free banking are set forth as economic, religious and social reasons. The shortages in foreign exchange and the need for foreign capital experienced in the period until and including the 1980s led to the establishment of interest-free banking for the purpose of expanding the shrinking economy. With a decree promulgated in 1983, 'Special Finance Houses' started their operations in Turkey. In this way, citizens that wish to preserve or utilize their savings in an 'interest-free' way were offered the chance to participate to the economic activity in a sense, and also the economy was supported in leaving behind the problematic period experienced and expanding outwards. Having been already adopted by the Turkish society, despite their relatively short history of 30 years, interest-free banks, or with a more current term 'Participation Banks' made significant progress in terms of the funds they collect, their business volumes and project capacities. The banks established in Turkey to carry out 'interest-free banking' are presented in the following table. 
Table 3: Interest Free Banks Established and Currently Operating in Turkey

\begin{tabular}{|l|l|l|}
\hline Bank Name & $\begin{array}{l}\text { Year } \\
\text { Establishment }\end{array}$ & Operation \\
\hline $\begin{array}{l}\text { Albaraka Turk Special Finance House } \\
\text { Inc. }\end{array}$ & 1985 & Operating \\
\hline Faisal Finance House Inc. & 1985 & Terminated \\
\hline Kuveyt Turk Foundation Finance & 1989 & Operating \\
\hline House Inc. & 1991 & Continues operation under \\
\hline Anadolu Finance House Inc. & 1995 & Liquidated \\
\hline Ihlas Finance House Inc. & 1996 & Operating \\
\hline Asya Finance House Inc. & 2005 & Operating \\
\hline Turkey Finance Participation Bank Inc. &
\end{tabular}

The first three among these were established completely with foreign capital; two of which still continue operation and the third one withdrew from the sector through 'merger'. The next three banks were established with fully domestic capital, yet could not continue in this way. In 2008, 60\% capital share of the Turkey Finance Participation Bank, established with complete domestic capital, was bought by the National Commercial Bank from Saudi Arabia, thus its capital and management was acquired by foreigners. One of the others was liquidated and the other withdrew from the sector through merger. In the end, Bankasya remains as the only 'domestic capital' Participation Bank still operating.

Participation Banks had their share from the process of 'restructuring' the financial system in Turkey that started in 2001, and their number was decreased to four. However, despite the decrease in their number, they maintained a stable growth after the crisis and their total assets which were 3.96 Billion TL. in 2002, increased to 56.1 Billion TL by the end of 2011 and to 70.03 Billion TL by the end of the year 2012. Thus, Participation Banks' assets grew by a 
striking 17.7 times from 2002 to 2012. On the other hand, 'Collected Funds/Deposits' increased by 14.9 times, 'Funds/Credits made available' increased by 22.8 times and finally Equities increased by 18.4 times.

Table 4: Development of Significant Balance Sheet Items of Participation Banks (Million TL.)

\begin{tabular}{|l|l|l|l|l|}
\hline Year & Assets & $\begin{array}{l}\text { Deposits/ } \\
\text { Collected Funds }\end{array}$ & $\begin{array}{l}\text { Credits/ } \\
\text { Funds made } \\
\text { available }\end{array}$ & Equities \\
\hline 2002 & 3.962 & 3.206 & 2.101 & 0.400 \\
\hline 2005 & 9.945 & 8.369 & 7.407 & 1.000 \\
\hline 2010 & 43.339. & 33.828 & 32.084 & 5.457 \\
\hline 2011 & 56.148 & 39.220 & 38.538 & 6.193 \\
\hline 2012 & 70.028 & 47.921 & 47.961 & 7.377 \\
\hline
\end{tabular}

Source: Participation Banks Association of Turkey

\subsection{Functioning of Participation Banking}

In the study conducted by Ozulucan and Deran (2009), operation principles of Participation Banking was summarized under five items. These were set forth as;

- absolute risk,

- financing enterprises with social productivity,

- financial risk belonging to the people that lend the capital,

- prohibition of interest and

- being associated with capital.

The primary and traditional function of banking is to collect the money of deposit owners and to make it available to those in need as credit. The primary function of Participation Banks is also the same. However, they differ from traditional banking in the ways they collect funds and make them available. Because funds are collected on the 'basis of participation to profit 
and loss' and are made available on the basis of trade or partnership, instead of providing cash directly.

In the essence of Participation Banking lies the 'prohibition of interest'. In many Verses in the Qur'an al Kerim (Rum 39, Nisa 160 and 161, Baqarah 275, 276 and 277 and Ali Imran 130) and in many Hadith Sharif of the prophet of Islam, the vicious nature and prohibition of interest is mentioned. On the other hand 'commerce' was described as lawful, or halal in Islamic terms. Thus, 'interest-free banking system' enlivens the economy by financing commerce/real exchange of goods and services, and also prevents factors such as speculation and usury that disrupt the market.

In all holy texts related with the subject, interest is regarded bad and prohibited. Interest based transactions have been the subject of many controversies among philosophers and thinkers, as well as the science of economy itself. According to Aristotle, money is merely a medium of exchange and does not produce anything by itself. The British economist Keynes, on the other hand, considers interest as an element that obstructs investments and sets forth an inverse relationship between the increase of investments and increase of interest (Yilmaz, 2010).

Another important factor in the functioning of interest-free banking system is the 'prohibition of transactions that are risky and involve uncertainties'. Funds are not provided through risky transactions, or through transactions that bear a possibility of the buyer or the seller incurring a loss or that may cause deceit.

Funds are collected in two ways from savers. First of these runs through 'drawing accounts', where saving holders deposit their savings to banks' 'private current accounts' not against interest or any income, but for the purpose of merely preserving their savings. Characteristics of these accounts are exactly the same with those of drawing accounts used in other banking systems. Savings in these accounts can be withdrawn either partially or fully at any time, are guaranteed to be paid back and do not bring in any income. However, in the required reserve account established by the Central Bank of the Turkish Republic (CBTR), the required reserves banks keep in their vaults at a certain percentage from collected deposits in TL and foreign currencies, also apply to Participation Banking. As in the past, CBTR occasionally pays interest or surplus to all banks, also including Participation Banks, for statutory reserves. However, since the implementation of interest is contrary to the establishment purposes of Participation Banks, such incomes from interest are not admitted to 
bank accounts but usually used in social activities outside of the field of banking (Coskun, 2008) or transferred to the Saving Deposit Insurance Fund (Aktepe, 119).

The second form of fund-raising is the 'profit and loss sharing accounts'. 'Dividend' is granted to these accounts at a certain maturity. Each currency collected in these accounts which can also be opened in foreign currency (foreign exchange) is grouped according to the types of money in the pool system. Each group's profit/loss amount is calculated by the maturity date of the savings and $20 \%$ or $25 \%$ of profit/loss left to the bank as a partner share; this share is determined by the maturity and the size of account. The remaining $75 \%$ or $80 \%$ is transferred to the account of the savings holder. The amount of the profit /loss for each group is unpredictable. But it is calculated and determined on due date of the account(Canbaz, 2012).

\section{Method}

This study compares the attitudes of traditional banks and participation banks to their customers on the basis of financial indicators. The comparison is conducted according to the five financial ratios proposed by Parashar and Ventakesh (2010): Capital adequacy, efficiency, profitability, liquidity and leverage ratios. In the analysis, the null hypothesis claiming that there is no difference between the means of deposit banks and participation banks using t-test.

Since t-test has a sample volume of less than 30 and used for equivalence of means, in order to establish reliability and validity of the results, it should fulfill normality and variance homogeneity criteria. T-test, established by William Gosset in 1990's, is widely used to compare the means of two samples. Statistical null hypothesis maintains that the mean of two variables should be the same for two groups (McDonald, 2009).

Senesen (2000) summarizes the testing of the mean of two main statistical populations:

Normal distributions $\mathrm{n}_{\mathrm{x}}$ and $\mathrm{n}_{\mathrm{y}}$ with the same variations and with $\mu_{\mathrm{x}}$ and $\mu_{\mathrm{y}}$ means are two independent, observed samples. If the observed sample variances $\operatorname{are} s_{x}{ }_{x}$ and $s^{2}$, an estimate of the combination of the variances for the statistical population can be calculated with:

$$
s^{2}=\frac{(n-1) s^{2}+(n-1) s^{2}}{x y y}
$$


In this case, if the observed sample means are $\bar{x}$ and, then the level of significance level of the following the following tests will be $\alpha$ :

i) The decision rule of testing the one of the null hypothesis $\mathrm{H}_{0}: \mu_{\mathrm{x}}-\mu_{\mathrm{y}}=\mathrm{D}_{0}$ or $\mathrm{H}_{0}: \mu_{\mathrm{x}}-$ $\mu_{\mathrm{y}} \leq \mathrm{D}_{0}$ with the opposite hypothesis $\mathrm{H}_{1}: \mu_{\mathrm{x}}-\mu_{\mathrm{y}}>\mathrm{D}_{0}$ is:

$$
\frac{\bar{x}-\bar{y}-D_{0}}{s \sqrt{n_{\underline{x}}+n_{\underline{y}}}}>t_{n_{x}+n_{y}-2, \alpha}
$$

In this case $\mathrm{H}_{0}$ should be rejected.

ii) The decision rule of testing $\mathrm{H}_{0}: \mu_{\mathrm{x}}-\mu_{\mathrm{y}}=\mathrm{D}_{0}$ hypothesis with the two-sided $\mathrm{H}_{1}: \mu_{\mathrm{x}}-\mu_{\mathrm{y}} \neq \mathrm{D}_{0}$ hypothesis is:

$$
\frac{\bar{x}-\bar{y}-D_{0}}{s \sqrt{\frac{n_{x}+n_{y}}{n_{x} n_{y}}}}<_{t_{n+n-2,}{ }_{x} \quad{ }_{2}} \text { or } \frac{\bar{x}-\bar{y}-D_{0}}{s \sqrt{\frac{n_{x}+n}{n_{x} n_{y}}}}>_{t_{n+n-2,-}{ }_{y}}
$$

In this case, $\mathrm{H}_{0}$ is rejected. Here $t_{n+n-2, \alpha}$ establishes the equation of $\mathrm{P}\left(t_{n+n-2}>t_{n+n-2, \alpha}\right)=\alpha$.

$t_{n_{x}+n,-2}$ follows the Student $\mathrm{t}$ distribution with $n_{x}+n_{y}-2$ free degree.

$\mathrm{T}$ distribution has two important hypotheses. These are the normal ways of distributing the data and the homogeneity of variance. If the data is varied normally and involves variance, Welch test developed by Welch (1951) is applied for testing the differences between the means. W, the test statistic of Welch, is calculated as follows (Ozdemir, 2006):

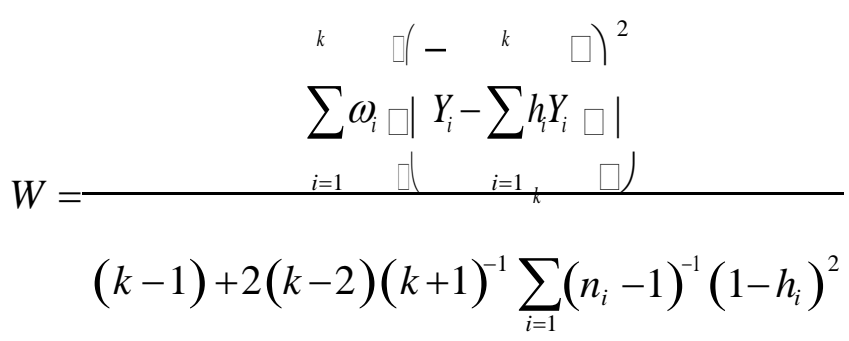


In equation $1, \bar{Y}_{i}$, the mean of group $\mathrm{i}, s_{i}^{2}$ sample variance, represents $\omega_{i}=\frac{n_{i}}{s^{2}}$ ve $h_{i}=\frac{\omega_{i}}{\sum}$.

$\mathrm{W}$ test statistical value is compared to the $\mathrm{F}$ critique value with $\left(\mathrm{k}-1, \mathrm{v}_{\mathrm{w}}\right)$ level of freedom at $\alpha$ significance level. In the case of $W>F_{k-1, v, 1-\alpha}$ the null hypothesis is rejected

\section{Ratios As Distinguishers}

In a study using ratios as a tool of classification between conventional banks and interest-free participation banks, it was shown that Islamic banks do not show clear differences in terms of profitability, but they are less risky (Parlakkaya \& Curuk, 2011). Also the theoretical studies of Akhan, (2010) and Özulucan and Deran, (2009) compared the banking services and clientoriented approach of participation banks. Bumin (2008), and Çetin and Bittrak (2010) conducted other studies comparing the profitability performances of participation and conventional banks. Another study conducted by Meriem Djennas, Mohamed Benbouziane and Mustapha Djennas reviewed the resistance of traditional banks and Islamic banks in North African countries, Turkey and GCC (Gulf Cooperation Council) against crises.

\subsection{Capital Adequacy Ratio}

As a result of the crisis in 2007 that rapidly spread to the whole world, 'solvency' has gained more significance especially for financial institutions. On the other hand, with Basel regulations, the use and significance of 'capital adequacy ratio' as a criterion of solvency was maximized. In 1988 G-10 countries established Basel Standards to reinforce the stability and soundness of the banking system. According to these standards, capital adequacy ratio is obtained by dividing the total into risk-weighted assets.

The complicated structure due to the variety of methods of calculation of capital adequacy ratio and definitions of 'capital' in different countries magnifies the risks and ambiguities. In this regard, there is a greater need for a consensus over a clear definition of 'risks' and necessary precautions (Ersoy, 2011). The level of \%8 ratio according to Basel I and the subsequent Basel II regulations, which was a response to the increase in derivative products, was regarded the limit of danger for the respective financial institution. However, in 2010, after the global financial crisis in 2010, the (Basel) Committee agreed on a definition of capital with higher quality and invented the 'capital conservation buffer' and fixed it at $10.5 \%$. 
Profitability Ratio was included in the analysis in three different ways like the efficiency ratio. The first of these is the 'Profitability 1' ratio, 'Net Profit / Total Assets' ratio. The other, 'Profitability 2' ratio, is the 'Net Income / Shareholders' equity' ratio. The final one is the 'Profitability 3' ratio, the 'Net Profit / Paid-in Capital' ratio. Thus, the relationship between 'Net Profit After Tax' and 'Total Assets' and 'Self and Paid-in Capital' was measured.

\subsection{Efficiency Ratio}

Another ratio group used to measure the efficiency of institutions is the 'efficiency ratio'. Since this study aims to determine the attitudes of banks towards customers especially during the crisis period from financial tables, ratios measuring the channels banks turned to and their incomes were used in the study. These ratios show which customers or income/revenue items banks prioritize. Hence, the attitudes of banks can be understood and the whether two bank types present different attitudes can be measured.

The first efficiency ratio is 'loans/ deposits' ratio. From another perspective, ratio means the ratio of the deposit to change into credit. Because deposits are regarded as the main source of loans extended by banks, this measure is important for customer preferences and target audiences. Target audience also indicates the profit that banks focus on.

The second efficiency ratio, efficiency 2, refers to the 'interests (dividends) gained from loans/ interests (dividends) paid to deposits' ratio. Ratio means the profit/interest making capacity of banks by raising funds and loaning them as credit as their main field of activity, or the relationship between interest/dividend paid to the deposit and interest/dividend gained from loans.

The third efficiency ratio, efficiency 3, is the ratio of (Deposit Interest (dividend) Expenses + Personnel Expenses)/Credit interest (dividend) income ratio. This is the ratio of the sum expenses including personnel expenses incurred in carrying out banking activities and interest paid for operating main activities to the sum of operating income / loan interest (dividend) income. In fact, the relationship between the basic operating expenses and revenues shows the capacity and efficiency of profitability.

Finally, another important item which takes place only in the balance sheets of banks apart from conventional loan is the 'securities income and portfolio'. This is one of the main distinguishing items between two types of banks. Conventional banks in Turkey for many years have attracted attention as major institutions that finance the debts of the public. Conventional banks, reflecting the traditional banking system before 2000 as closed 
competition and the real economy, made easy and big profits through this channel. Although its importance began to decline, this gain still continues.

\subsection{Liquidity Ratio}

Liquidity Ratio, is known as the main indicator causing financial failure, or bankruptcy of banks (Candemir, 2011). For this reason, taking past experiences into account, bank managers and authorities largely focused on liquidity management.

Typically, the ratio of liquidity is determined as 'liquidity 1 'and 'liquidity 2' ratio and occurs as

Liquidity 1 Ratio $=($ Cash + Securities Portfolio $) /$ Short-Term Debt,

Liquidity 2 Ratio $=($ Cash + Securities Portfolio + Loans $) /$ Total Liabilities

\subsection{Leverage Ratio}

Leverage, in this study is examined as 'Equity / Assets' ratio and refers to the opposite of 'liabilities / assets'. Banks are businesses with very high financial leverage. Liability structure of banks mainly consists of short-term funds with debt quality and shareholders' funds small and limited resources (Ersoy, 2012).

\section{Empirical Evidence}

This study aims examining the differences between deposit banks and participation banks in terms of their attitude towards customers caused by their basic working principles as reflected by the indicators (ratio) in financial statements. Financial indicators have been used as defined in the previous section, and this data is based on the financial statements available in the official website of the BRSA. This study tests the two different types of banks with different principles of operation and uses the data gathered during the period between 2002 and 2011.

In the test of attitudes towards customers of two types of banks, it was used the data from the period of 2002-2011 years which the global financial crisisn was happened.

For this purpose, the two data sets from two periods, before and after the economic crisis of 2008, were analyzed for each type of bank. Thus, the attitudes towards customers and the market were determined according to trends observed in ratios. In the previous section, Table 1 shows the sum of 330 observations and analysis were conducted for 33 banks from two different types. 
Table 5 below illustrates the analysis of the descriptive statistics of ten ratios. According to the results in this table, Capital Adequacy ratio has the highest average amongst other ratios. Profitability Ratio has the lowest average and standard deviation.

Table 5: Descriptive Statistics of the Financial Indicators of the Banks (2002-2011)

\begin{tabular}{|c|c|c|c|c|c|c|}
\hline Ratios & Banks & Average & Median & $\begin{array}{l}\text { Standard } \\
\text { Deviation }\end{array}$ & $\begin{array}{c}\text { Minimum } \\
\text { Value }\end{array}$ & $\begin{array}{c}\text { Maximum } \\
\text { Value }\end{array}$ \\
\hline \multirow{2}{*}{$\begin{array}{c}\text { Capital } \\
\text { Adequacy } \\
\text { Ratio }\end{array}$} & $\begin{array}{l}\text { Deposit } \\
\text { Banks }\end{array}$ & 0.205 & 0.195 & 4.19 & 0.155 & $0.281 *$ \\
\hline & $\begin{array}{c}\text { Participation } \\
\text { Banks }\end{array}$ & 0.149 & 0.152 & 1.36 & 0.124 & 0.165 \\
\hline \multirow{2}{*}{$\begin{array}{l}\text { Profitability } \\
1 \text { Ratio }\end{array}$} & $\begin{array}{l}\text { Deposit } \\
\text { Banks }\end{array}$ & 0.019 & 0.021 & $0.004^{*}$ & $0.011^{*}$ & 0.024 \\
\hline & $\begin{array}{c}\text { Participation } \\
\text { Banks }\end{array}$ & 0.022 & 0.025 & 0.005 & 0.014 & 0.028 \\
\hline \multirow{2}{*}{$\begin{array}{c}\text { Profitability } \\
2 \text { Ratio }\end{array}$} & $\begin{array}{l}\text { Deposit } \\
\text { Banks }\end{array}$ & 0.162 & 0.164 & 0.054 & 0.106 & 0.208 \\
\hline & $\begin{array}{c}\text { Participation } \\
\text { Banks }\end{array}$ & 0.191 & 0.173 & 0.054 & 0.129 & 0.263 \\
\hline \multirow{2}{*}{$\begin{array}{c}\text { Profitability } \\
3 \text { Ratio }\end{array}$} & $\begin{array}{l}\text { Deposit } \\
\text { Banks }\end{array}$ & 0.451 & 0.483 & 0.117 & 0.228 & 0.586 \\
\hline & $\begin{array}{c}\text { Participation } \\
\text { Banks }\end{array}$ & 0.315 & 0.262 & 0.09 & 0.245 & 0.47 \\
\hline \multirow{2}{*}{$\begin{array}{c}\text { Efficiency } 1 \\
\text { Ratio }\end{array}$} & $\begin{array}{l}\text { Deposit } \\
\text { Banks }\end{array}$ & 0.625 & 0.705 & 0.198 & 0.324 & 0.946 \\
\hline & $\begin{array}{c}\text { Participation } \\
\text { Banks }\end{array}$ & 0.897 & 0.926 & 0.07 & 0.773 & 0.982 \\
\hline
\end{tabular}




\begin{tabular}{|c|c|c|c|c|c|c|}
\hline \multirow{2}{*}{$\begin{array}{c}\text { Efficiency } 2 \\
\text { Ratio }\end{array}$} & $\begin{array}{l}\text { Deposit } \\
\text { Banks }\end{array}$ & 1.02 & 1.04 & 0.406 & 0.37 & 1.52 \\
\hline & $\begin{array}{c}\text { Participation } \\
\text { Banks }\end{array}$ & 1.66 & 1.62 & 0.144 & 1.52 & 1.95 \\
\hline \multirow{2}{*}{$\begin{array}{c}\text { Efficiency } 3 \\
\text { Ratio }\end{array}$} & $\begin{array}{l}\text { Deposit } \\
\text { Banks }\end{array}$ & 1.472 & 1.18 & 0.779 & 0.88 & 3.03 \\
\hline & $\begin{array}{c}\text { Participation } \\
\text { Banks }\end{array}$ & 0.824 & 0.82 & 0.044 & 0.74 & 0.89 \\
\hline \multirow{2}{*}{$\begin{array}{c}\text { Liquidity } 1 \\
\text { Ratio }\end{array}$} & $\begin{array}{r}\text { Deposit } \\
\text { Banks }\end{array}$ & 0.003 & 0.0029 & 0.0002 & 0.0026 & 0.0034 \\
\hline & $\begin{array}{c}\text { Participation } \\
\text { Banks }\end{array}$ & 0.0012 & 0.0012 & 0.0001 & 0.001 & 0.0013 \\
\hline \multirow{2}{*}{$\begin{array}{c}\text { Liquidity } 2 \\
\text { Ratio }\end{array}$} & $\begin{array}{l}\text { Deposit } \\
\text { Banks }\end{array}$ & 0.859 & 0.884 & 0.098 & 0.649 & 0.96 \\
\hline & $\begin{array}{c}\text { Participation } \\
\text { Banks }\end{array}$ & 1.0057 & 1.0089 & 0.032 & 0.942 & 1.041 \\
\hline \multirow{2}{*}{$\begin{array}{c}\text { Leverage } \\
\text { Ratio }\end{array}$} & $\begin{array}{l}\text { Deposit } \\
\text { Banks }\end{array}$ & 0.119 & 0.12 & 0.01 & 0.105 & 0.138 \\
\hline & $\begin{array}{c}\text { Participation } \\
\text { Banks }\end{array}$ & 0.12 & 0.121 & 0.015 & 0.09 & 0.144 \\
\hline
\end{tabular}

*Highest and lowest values

Figure 3 graphs shows the time series graphs of the ratios included in the analysis. The most important point to be examined at this point is the trends or the change before and after the 2008 crisis. The second important point is trends in the ratios under efficiency ratios which present the difference between the two types of banks clearly. 

It can be observed that according to the Basel Capital Adequacy ratio both banks exceed the critical average of $8 \%$. In contrast, capital adequacy ratio has the highest ratio in the standard deviation. Although the standard deviation is high, the lowest level of the ratio still did not stay under the critical value during the period after 2002 .

Profitability ratio 1, is the 'Net Profit / Total Assets' ratio. Participation Banks were in continuous decline since 2006 and this trend continued until the end of 2011. In contrast, the deposit banks, followed a fluctuating course, and after the crisis the trend went upwards. The banks in loss before 2002 (Atasoy, 2007) increased their profitability this year despite a decreasing trend.

Profitability ratio 2 is the 'Net Profit / Shareholders' Equity Ratio' and again followed a fluctuating course in deposit banks. However, until the end of 2011, like the ratio of Profitability 1, the trend indicates reduction. Again, the Participation Banks had a tendency to decrease on a regular basis.

Profitability ratio 3 , refers to 'the ratio of net profit to paid capital' and although it was increasing in participation banks until 2007, the trend was a rapid decline from this year on. However, this declining trend turned into a horizontal course with the crisis. Similar to the other profitability ratios, deposits in banks had a fluctuating profitability ratio. Ratio after the crisis showed an increasing trend but the trend began to decline again after two periods. Meanwhile, between 2005 and 2008 experienced significant breaks by taking a 'dip'.

Efficiency 1 ratio, in other words 'ratio of loans to deposits ', in participation banks, in the 2006-2008 period followed a declining trend and after 2008 the trend continued. After 2009 the trend changed to a significant increase. The average in this period was 89.7 percent. In deposit banks, this ratio, increased steadily from 2002 until 2007, but starting this year until 2009 there was a horizontal or even a downward slope, then the trend increased. However, the average of the period was 62.5 percent. Thus, for every $100 \mathrm{TL}$, participation banks contributed TL 90 fund to the real economy while deposit banks could provide only TL 62.5 credit. Ratio of the banks is considered an indicator of how much banks focus on their main activities.

Efficiency 2 ratio, when 'Interest on loans (dividend) / Interest(dividend) paid to the deposits' ratio is examined, it is noticed that crisis in 2008 did not change the increase trend in participation banks and the ratio gradually increased to an average rate of $1.66 \%$. Thus, participation banks made a big net gain from their main activities. Therefore, the focus of the 
participation banks on the income provided through these channels paid off. In contrast, the situation was different for deposit banks. Until 2007 the interest income deposit banks gained from loans remained below the interest expense paid to the deposits. Since 2007, loan interest income from this year gradually started to meet the interest paid to deposits by increasing rapidly, however, the ration-term average could rise up to only $1.02 \%$. Thus, deposit banks demonstrated the possibility of making profit from the channel of main operations like the participation banks in recent years. As the Efficiency 1 ratio shows that as deposit money banks using their credits in other areas before 2002 turned to their main operations (real economy and market) which led to an increase in the ratio of deposits in turning into credit and interest income from credits. With this ratio the capacity of making income for participation banks was found to be much more successful than deposit banks. For this study this ratio is significant as an indicator of the tendency of banks to turn to the target audience (customers) to achieve their objectives.

Efficiency 3 ratio compares 'the expenses from operating revenues of banks including personnel expences' to income. In this study, when Deposit Interest (dividend) Expenses +Personnel Expenses / Loan interest (dividend) income ratios are compared, it was found out that, with the crisis in 2008, for participation banks decline trend accelerated. In other words, after 2002, including the crisis period, with the effect of the 'restructuring' in the sector dividend income, main operating expenses paid in exchange for dividend income continued for some time and per TL 100 the average main operating expense was 82.4 TL. For deposits banks the ratio was continuous and stable and remained flat from 2002 until 2011.Banks whose operating expenses were 3-fold of their revenues, started to expend TL 87.5 per TL 100 they earned. However, despite this development period, the average ratio of operating income derived from operating expenses could only go down to 1.47 Thus, despite the positive developments, in recent years deposit money banks could not make a net positive income from the difference between main operating income and expenses.

Finally, from the perspective of conventional banking, income from the investment in securities exported by public sector as an alternative to the credits transferred to economy after 1980 should be studied. Securities portfolio, which is not considered an area of investme nt by participation banks due to their principles, was heavily used by banks as an easy and risk-free field for a long time. Parallel to the developments in the ratio of credit / deposit in the last ten years, portfolio of securities started to decline relatively in bank balance sheets, but still it stands as the most important item of income. As shown in the chart below, 
deposit banks earned 15 to 30 Billion TL of securities portfolio interest annually for the last ten years. In contrast, the income from this item, which started to appear in balance sheets recently, is very limited for participation banks.

Figure 2: Interest Income of Deposit Banks from Securities (2002-2011) (Billion TL.)

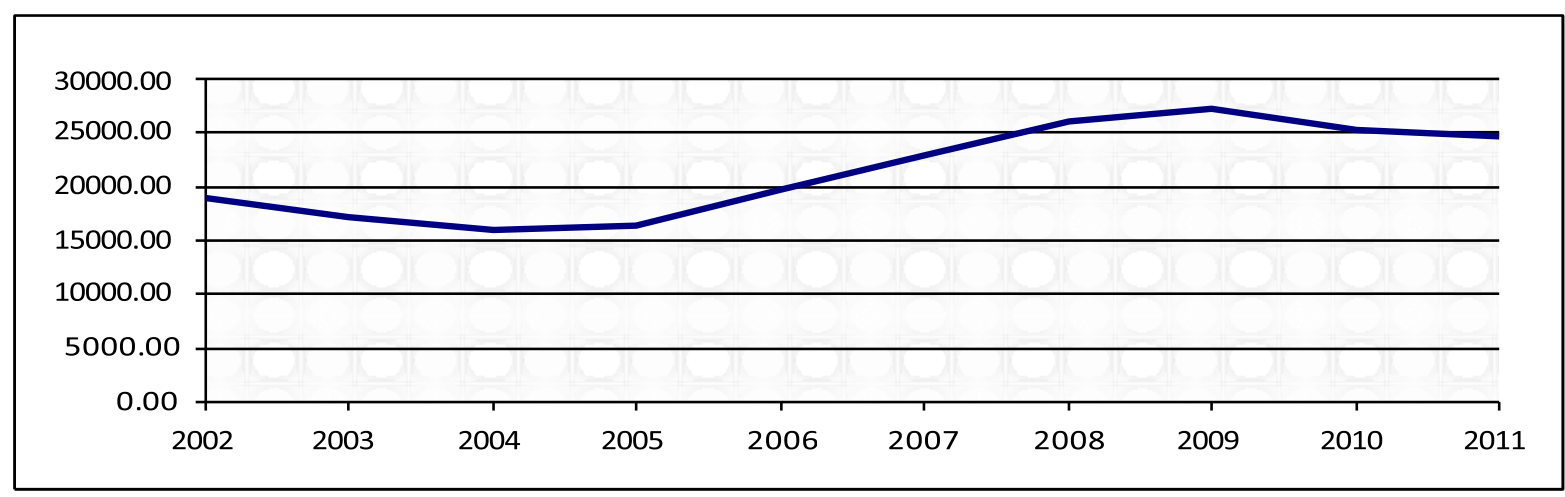

Liquidity Ratio 1 of participation and deposit banks followed a fluctuating trend. However, immediately after the crisis, there was a decrease in participation banks and increase in deposit banks. Liquidity ratio 2, on the other hand, showed an increasing trend for both banks immediately after the crisis.

Leverage (Equity / Assets) ratio was heavily influenced by the crisis for participation banks. This ratio increased rapidly with the input of the compulsory capital between 2005-2008, but after 2008, it started to decrease sharply as a result of the inability to grow in line with the growth of the balance sheets.

Figure 3: Time Series of Ratios
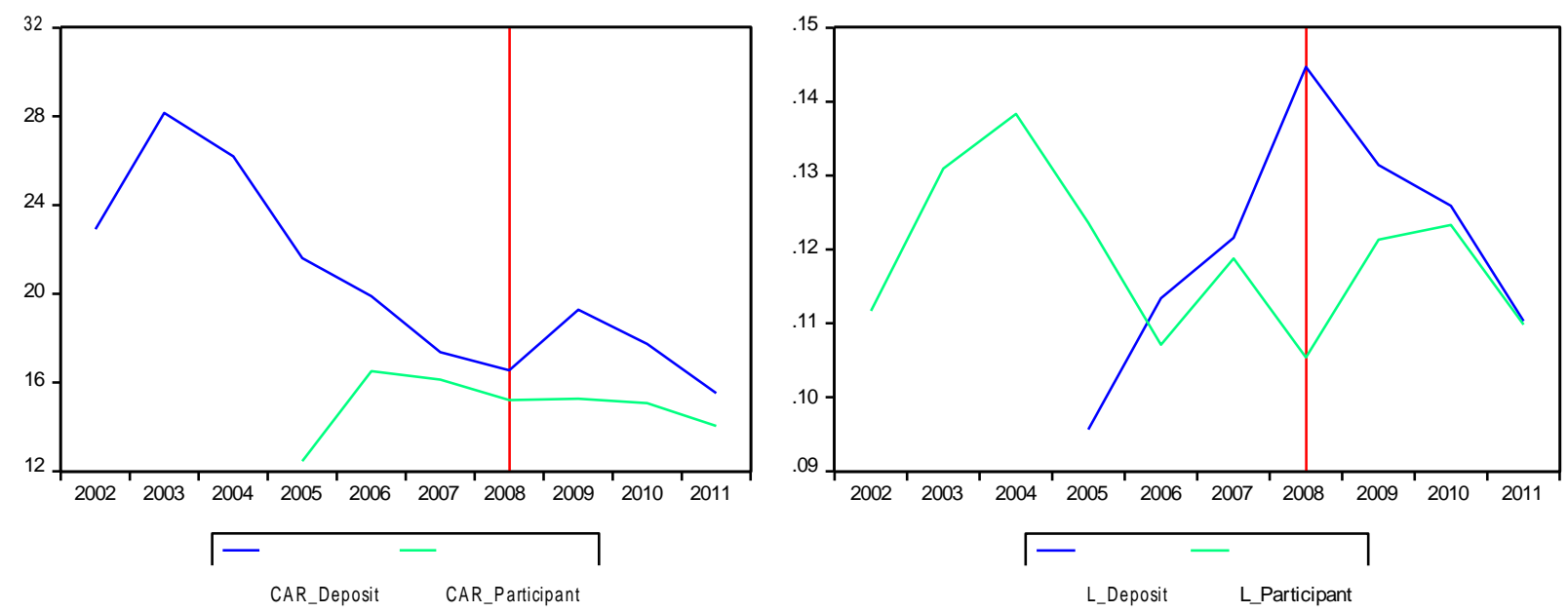

Capital Adequacy and Leverage Ratio Graphs 

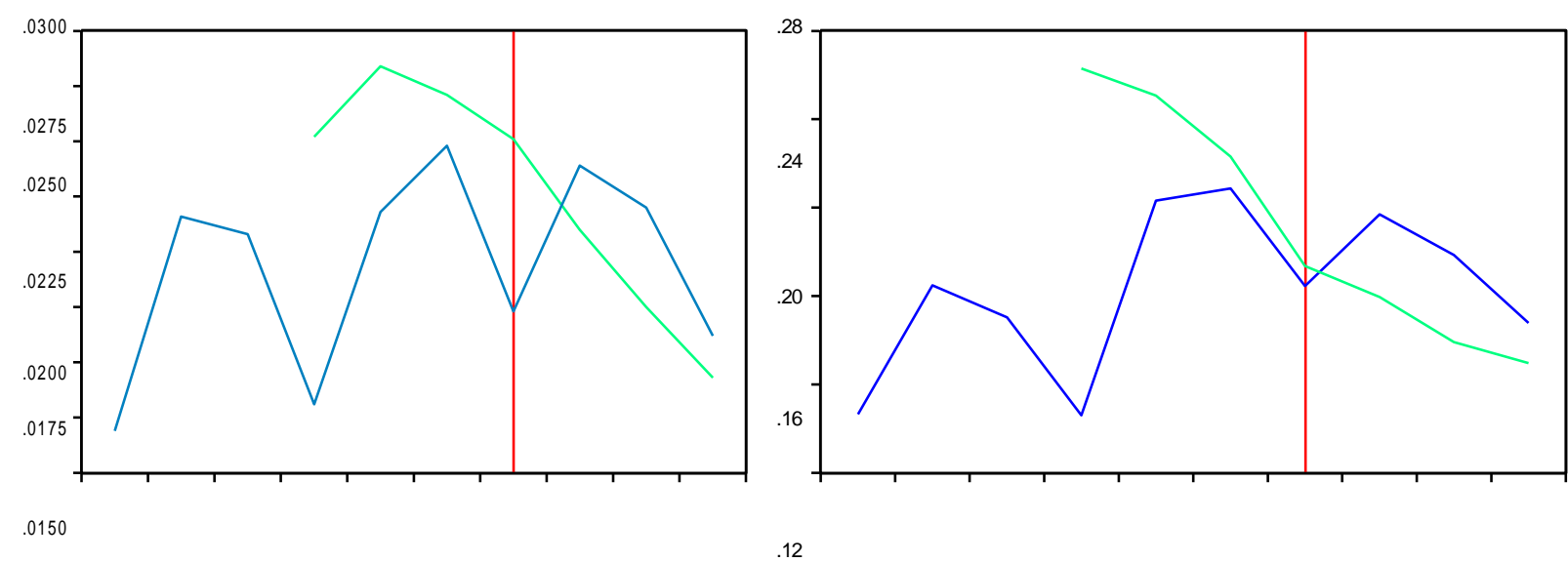

.0125

.0100

$2002 \quad 2003 \quad 2004 \quad 2005 \quad 2006 \quad 2007 \quad 2008 \quad 2009 \quad 2010 \quad 2011$ $\begin{array}{llllllllll}2002 & 2003 & 2004 & 2005 & 2006 & 2007 & 2008 & 2009 & 2010 & 2011\end{array}$

—-P1_Participant —P1_Deposit

- P2_Deposit — P2_Participant

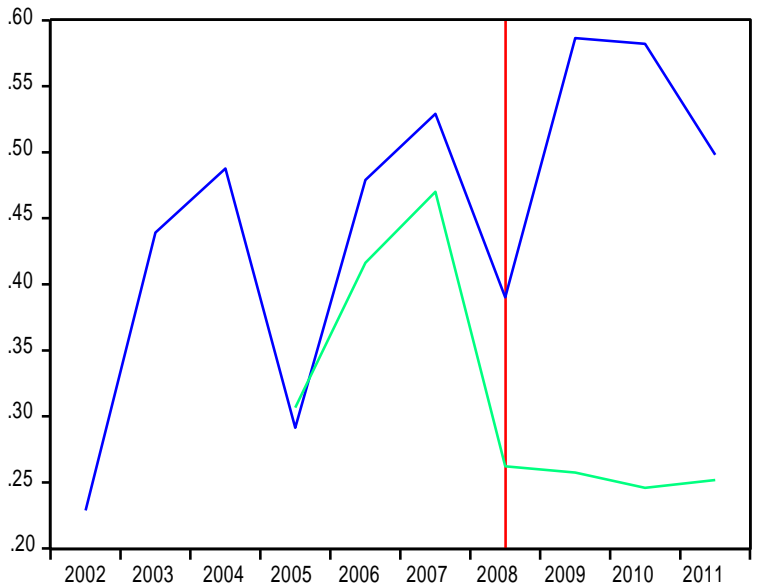

-P3_Deposit _ P3_Participant

Profitability Ratio Graphs

1.0

0.9

0.8

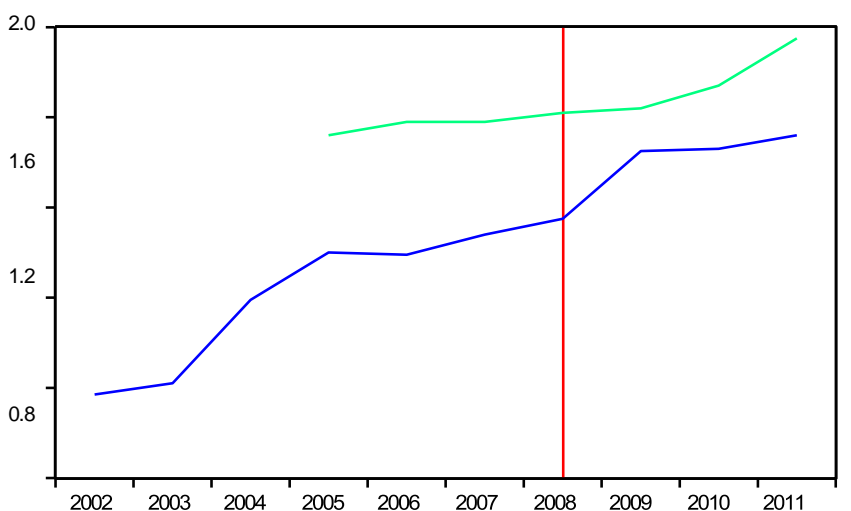




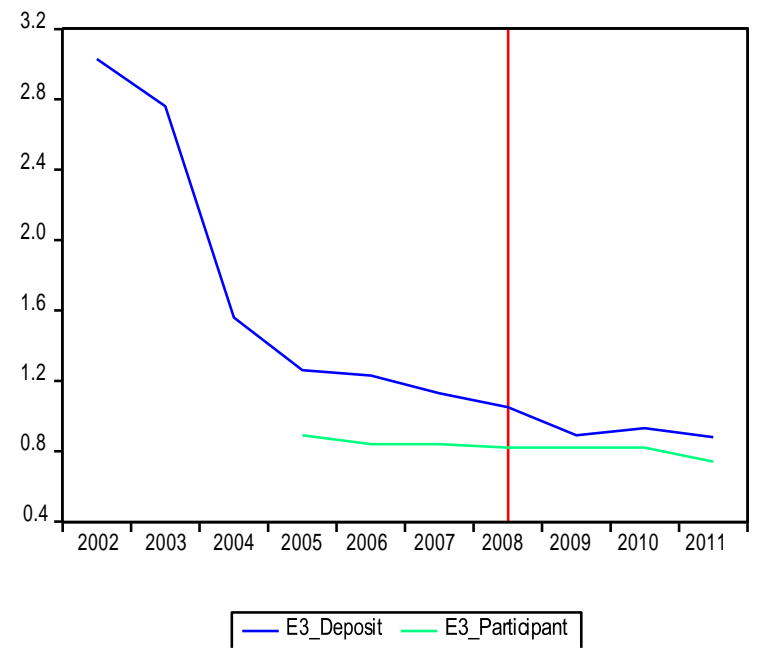

Efficiency Ratio Graphs

.0035

.0030

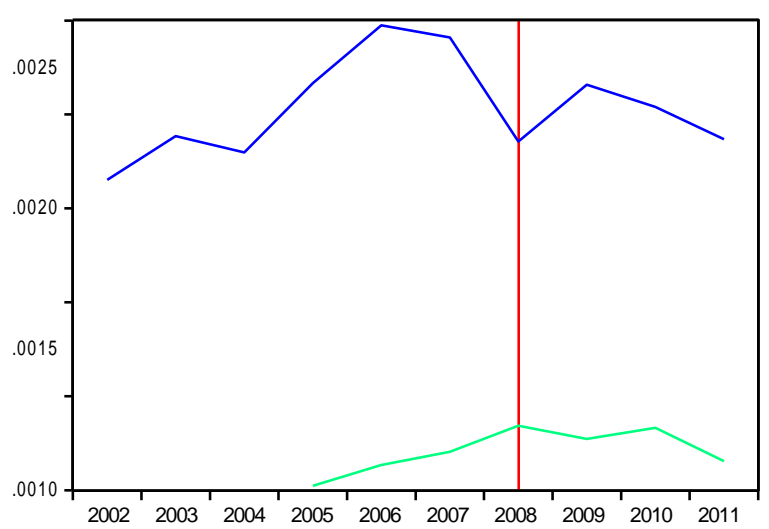

11

1.0

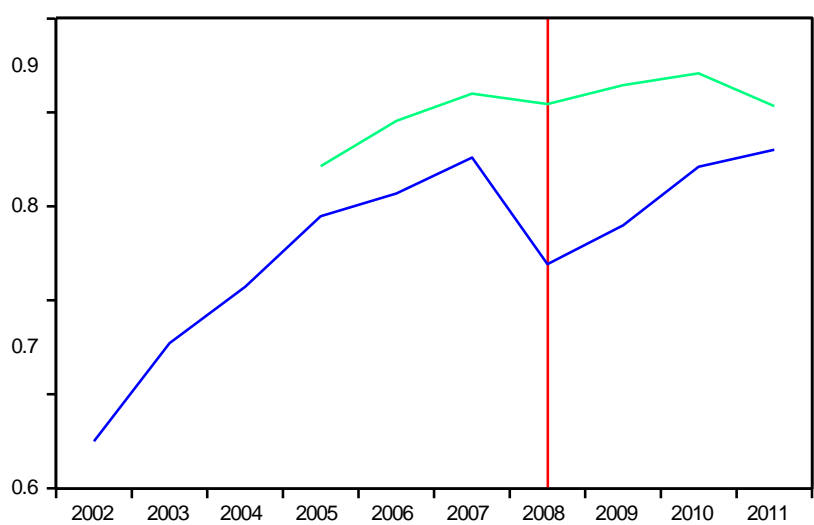

- L1_Deposit _L1_Participant

- L2_Deposit — L2_Participant

\section{Liquidty Ratio Graphs}

In order to test whether there are any differences between the means, the requirements of normal distribution and homogeneous should be met for t-test. In this study, for normality test the Jarque-Bera normality test (JB) and for equal variance $F$ test were used. According to the results in Table 6, all of the variables are proven for the "data is homogenously distributed" null hypothesis at 0.05 significance through JB test. However, according to the F-test results at 0.05 significance, "groups are equally varied" null hypothesis is valid for all groups except 


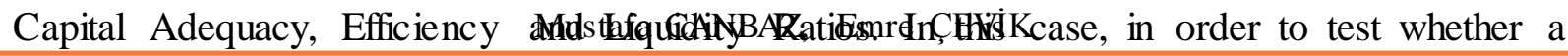
difference exists between the variables, instead of t-test, Welch test results will be considered. 
Table 6: Jarque-Bera and F-Test Results of the Bank Financial Indicators

\begin{tabular}{|c|c|c|c|}
\hline Ratios & Banks & $\begin{array}{c}\text { JB Test } \\
\text { Statistics }\end{array}$ & $\begin{array}{r}\text { F Test } \\
\text { Statistics }\end{array}$ \\
\hline \multirow{2}{*}{$\begin{array}{l}\text { Capital } \\
\text { Ratio }\end{array}$} & Deposit Banks & $0.935(0.626)^{*}$ & \multirow[b]{2}{*}{$9.501(0.0036)$} \\
\hline & $\begin{array}{c}\text { Participation } \\
\text { Banks }\end{array}$ & $0.751(0.686)$ & \\
\hline \multirow[b]{2}{*}{ Profitability 1 Ratio } & Deposit Banks & $0.932(0.627)$ & \multirow[b]{2}{*}{$1.374(0.72)$} \\
\hline & $\begin{array}{l}\text { Participation } \\
\text { Banks }\end{array}$ & $0.704(0.703$ & \\
\hline \multirow[b]{2}{*}{ Profitability 2 Ratio } & Deposit Banks & $0.631(0.729)$ & \multirow[b]{2}{*}{$2.203(0.348)$} \\
\hline & $\begin{array}{c}\text { Participation } \\
\text { Banks }\end{array}$ & $0.775(0.678)$ & \\
\hline \multirow[b]{2}{*}{ Profitability 3 Ratio } & Deposit Banks & $0.986(0.61)$ & \multirow[b]{2}{*}{$1.685(0.462)$} \\
\hline & $\begin{array}{l}\text { Participation } \\
\text { Banks }\end{array}$ & $1.187(0.552)$ & \\
\hline \multirow[b]{2}{*}{ Efficiency 1 Ratio } & Deposit Banks & $0.583(0.746)$ & \multirow[b]{2}{*}{$7.567(0.0081)$} \\
\hline & $\begin{array}{l}\text { Participation } \\
\text { Banks }\end{array}$ & $0.647(0.723)$ & \\
\hline \multirow[b]{2}{*}{ Efficiency 2 Ratio } & Deposit Banks & $0.647(0.723)$ & \multirow[b]{2}{*}{$7.930(0.0069)$} \\
\hline & $\begin{array}{c}\text { Participation } \\
\text { Banks }\end{array}$ & $1.802(0.406)$ & \\
\hline \multirow[b]{2}{*}{ Efficiency 3 Ratio } & Deposit Banks & $2.762(0.251)$ & \multirow{2}{*}{$\begin{array}{l}304.923 \\
(0.0000)\end{array}$} \\
\hline & $\begin{array}{c}\text { Participation } \\
\text { Banks }\end{array}$ & $0.492(0.781)$ & \\
\hline
\end{tabular}




\begin{tabular}{|c|c|c|c|}
\hline \multirow{2}{*}{ Liquidity 1 Ratio } & Deposit Banks & $0.664(0.717)$ & \multirow{2}{*}{$5.39(0.025)$} \\
\hline & $\begin{array}{c}\text { Participation } \\
\text { Banks }\end{array}$ & $0.414(0.812)$ & \\
\hline \multirow{2}{*}{ Liquidity 2 Ratio } & Deposit Banks & $1.561(0.458)$ & \multirow{2}{*}{$9.321(0.0039)$} \\
\hline & $\begin{array}{c}\text { Participation } \\
\text { Banks }\end{array}$ & $1.239(0.538)$ & \\
\hline \multirow[b]{2}{*}{ Leverage Ratio } & Deposit Banks & $0.517(0.772)$ & \multirow[b]{2}{*}{$2.204(0.348)$} \\
\hline & $\begin{array}{l}\text { Participation } \\
\text { Banks }\end{array}$ & $0.136 \quad .934)$ & \\
\hline
\end{tabular}

*Results in the brackets are the probability results corresponding to the test statistical results

The pre-crisis and post-crisis average financial indicators of the deposit banks and participation banks in Table 7 shows whether there is any difference between the test results. The differences in how banks varied in their orientation within their own category and among other categories was compared

As a result of this analysis, 'there is no difference between the averages before the crisis and after crisis' null hypothesis, at 0.05 significance level;

- Is not accepted for deposits banks except 'Capital Adequacy, Efficiency Ratios of 1 and $2^{\prime}-$

- Is not accepted for participation banks for Profitability Ratios 1 and 2.

Therefore, participation banks are not different from conventional banks in terms of Profitability 1 and 2 ratios. 
Table 7: The Results of Means of The Banking Financial Indicators Before and After The Crisis

\begin{tabular}{|c|c|c|c|c|c|c|}
\hline \multirow{3}{*}{ Ratios } & \multicolumn{3}{|c|}{ Deposit Banks } & \multicolumn{3}{|c|}{ Participant Banks } \\
\hline & \multicolumn{2}{|c|}{ Averages } & \multirow{2}{*}{$\begin{array}{c}\text { Test } \\
\text { Statistics }\end{array}$} & \multicolumn{2}{|c|}{ Averages } & \multirow{2}{*}{$\begin{array}{c}\text { Test } \\
\text { Statistics }\end{array}$} \\
\hline & $\begin{array}{l}\text { Before } \\
\text { Crisis }\end{array}$ & $\begin{array}{l}\text { After } \\
\text { Crisis }\end{array}$ & & $\begin{array}{l}\text { Before } \\
\text { Crisis }\end{array}$ & $\begin{array}{l}\text { After } \\
\text { Crisis }\end{array}$ & \\
\hline Capital Adequacy & 0.226 & 0.172 & $\begin{array}{c}2.539 \\
(0.035)^{*}\end{array}$ & 0.150 & 0.148 & $\begin{array}{c}0.116 \\
(0.911)\end{array}$ \\
\hline Profitability 1 & 0.018 & 0.019 & $\begin{array}{l}-0.313 \\
(0.762)\end{array}$ & 0.026 & 0.019 & $\begin{array}{r}2.956 \\
(0.041)\end{array}$ \\
\hline Profitability 2 & 0.156 & 0.171 & $\begin{array}{l}-0.727 \\
(0.49)\end{array}$ & 0.245 & 0.15 & $\begin{array}{c}6.17 \\
(0.003)\end{array}$ \\
\hline Profitability 3 & 0.409 & 0.514 & $\begin{array}{l}-1.556 \\
(0.158)\end{array}$ & 0.397 & 0.254 & $\begin{array}{c}2.967 \\
(0.097)\end{array}$ \\
\hline Efficiency 1 & 0.542 & 0.817 & $\begin{array}{l}-3.620 \\
(0.011)\end{array}$ & 0.852 & 0.007 & $\begin{array}{l}-1.43 \\
(0.248)\end{array}$ \\
\hline Efficiency 2 & 0.775 & 1.395 & $\begin{array}{l}-4.009 \\
(0.006)\end{array}$ & 1.56 & 1.737 & $\begin{array}{l}-1.951 \\
(0.108)\end{array}$ \\
\hline Efficiency 3 & 1.828 & 0.936 & $\begin{array}{c}2.068 \\
(0.072)\end{array}$ & 0.857 & 0.798 & $\begin{array}{c}2.372 \\
(0.063)\end{array}$ \\
\hline Liquidity1 & 0.003 & 0.002 & $\begin{array}{c}0.537 \\
(0.607)\end{array}$ & 0.0011 & 0.0012 & $\begin{array}{l}-2.288 \\
(0.083)\end{array}$ \\
\hline Liquidity 2 & 0.829 & 0.905 & $\begin{array}{l}-1.408 \\
(0.196)\end{array}$ & 0.984 & 1.021 & $\begin{array}{l}-1.538 \\
(0.221)\end{array}$ \\
\hline Leverage & 0.121 & 0.114 & 0.982 & 0.1102 & 0.128 & -1.69 \\
\hline
\end{tabular}




\begin{tabular}{|l|l|l|l|l|l|l|}
\hline & & & $(0.354)$ & & & $(0.151)$ \\
\hline
\end{tabular}

*Values in brackets are the probability values corresponding to the critical value

Table 8 shows the analysis of the interaction of the financial indicator averages in participation and deposit banks before and after the crisis. In order to understand the results in Table 8, the following hypotheses should be understood as follows:

1 .

$$
H_{0}: \mathrm{CAR}_{\text {Participant }} \leq \mathrm{CAR}_{\text {Deposit }}
$$

$$
H_{1}: \mathrm{CAR}_{\text {Participant }}>\mathrm{CAR}_{\text {Deposit }}
$$

2.

$$
H_{0}: \text { Profibility Ratio } \text { Participant } \leq \text { Profibility Ratio }_{\text {Deposit }}
$$

$$
H_{1} \text { : Profibility Ratio }{ }_{\text {Participant }}>\text { Profibility Ratio }_{\text {Deposit }}
$$

3.

$$
H_{0}: \text { Efficiency Ratio }_{\text {Participant }} \leq \text { Efficiency Ratio }_{\text {Deposit }}
$$

$$
H_{1} \text { : Efficiency Ratio } \text { Participant }>\text { Efficiency Ratio }_{\text {Deposit }}
$$

4.

$$
H_{0}: \text { Liquidity Ratio }_{\text {Participant }} \leq \text { Liquidity Ratio }_{\text {Deposit }}
$$

$$
H_{1}: \text { Liquidity Ratio }_{\text {Participant }}>\text { Liquidity Ratio }_{\text {Deposit }}
$$

5.

$$
H_{0}: \text { Leverage Ratio }{ }_{\text {Participant }} \leq \text { Leverage Ratio }_{\text {Deposit }}
$$

$$
H_{1} \text { : Leverage Ratio }_{\text {Participant }}>\text { Leverage Ratio }_{\text {Deposit }}
$$

The following findings are achieved when the results in Table 8 are considered in conjunction with the hypotheses above. Results in Table 8 show whether there was any difference between the ratio averages for the included ratios pre-crisis and post-crisis. For example, the null hypothesis for the capital adequacy ratio (CAR) is "the average capital adequacy ratio of the participation banks is not greater than the capital adequacy ratio of deposit banks". These hypotheses summarized in Table 8 are evaluated for the pre-crisis and post crisis.

The hypotheses for the capital adequacy ratio test are as follows

- $\mathrm{H}_{0}$ : The pre-crisis capital adequacy ratio average of the participation banks is not greater than the pre-crisis capital adequacy ratio average of the deposit banks

- $\mathrm{H}_{1}$ : The pre-crisis capital adequacy ratio average of the participation banks is greater than the pre-crisis capital adequacy ratio average of the deposit banks.

In the post-crisis period, the tested hypotheses for the same ratio are as follows; 
- $\mathrm{H}_{0}$ : The post-crisis capital adequacy ratio average of participation banks is not greater than the post-crisis capital adequacy ratio average of deposit banks.

- $\mathrm{H}_{1}$ : The post-crisis capital adequacy ratio average of participation banks is greater than the post-crisis capital adequacy ratio average of deposit banks.

The average test statistic of the pre-crisis comparison of capital adequacy ratio was 3682 . This value corresponds to the probability value of 0.003 . At 0.05 significance level, "the pre-crisis capital adequacy ratio average of the participation banks is not greater than the pre-crisis capital adequacy ratio average of the deposit banks" null hypothesis is rejected. Therefore, the alternative hypothesis "The pre-crisis capital adequacy ratio average of the participation banks is greater than the pre-crisis capital adequacy ratio average of the deposit banks“" is accepted.

The test result for the null hypothesis which tests the average of capital adequacy ratio for deposit and participation banks in the post-crisis period as "The post-crisis capital adequacy ratio average of participation banks is not greater than the post-crisis capital adequacy ratio average of deposit banks" is 2.758 and corresponds to the probability level of 0.025 . The null hypothesis is rejected and the alternative "The post-crisis capital adequacy ratio average of participation banks is greater than the post-crisis capital adequacy ratio average of deposit banks" hypothesis is accepted.

As noted above, in this part of the analysis the average ratio between the averages of the two banks in terms of species were compared before and after the crisis. Hypotheses also apply for other ratios.

The first of the profitability ratios (Profitability 1) test statistic for the pre-crisis period was found to be -3.39 and the probability value corresponding to this statistic was found to be 0.0058. Thus, null hypothesis is rejected for the pre-crisis period. Therefore, the average profitability ratio of the Participation Banks in the pre-crisis period was higher than the average of deposit banks in the same period. However, when the test statistic and probability value for the period after the crisis are examined together, the null hypothesis cannot be rejected. In other words, the average profitability ratio of the Participation Banks in the postcrisis period was not higher than the average of deposit banks in the same period.

When the test statistics for Profitability 2 ratio are analyzed, it is noticed that in this situation this ratio is the same as the ratio of 1 . Although during the pre-crisis period, the average ratio for participation banks was higher than the average of deposit banks, the average ratio during the post-crisis the average ratio of the participation banks was not higher than deposits banks. 
In the case of Profitability 3 analysis, the results were opposite to the results of profitability 1 and 2 . While before the crisis, the average ratio for profitability 3 for participation banks was not higher than deposits banks, it has been concluded that in the post-crisis period, the average ratio for the participation banks was higher than the deposit banks' profitability 3 results.

The analys is results for the first of the efficiency ratios (Event 1 Ratio) shows that the null hypothesis is rejected for both periods. The average activity 1 participation ratio of the precrisis and post-crisis periods for participation banks was higher than deposit banks. The same situation applies ratios of 1 and 2. All three ratios for the activity shows that the null hypotheses "The pre-crisis efficiency ratio average of the participation banks is not greater than the pre-crisis average of the deposit banks" and "The post-crisis average of participation banks is not greater than the post-crisis average of deposit banks" are rejected.

The analysis results for liquidity ratios are the same as the results of the efficiency ratios. Liquidity Ratio averages for participation banks is higher than the deposit banks for the precrisis and post-crisis periods.

Finally, the null hypothesis "the pre-crisis leverage ratio average of participation banks is not higher than the pre-crisis leverage ratio of deposit banks" is accepted with 1.3402 test statistic, 0.111 probability value and 0.05 significance level. On the other hand, the null hypothesis 'the post-crisis leverage ratio average of participation banks is not higher than the post-crisis leverage average ratio of deposit banks" cannot be rejected at -1.571 test statistics, 0.083 probability value and 0.05 significance level.

Table 8: Seasonal Test Results of the Financial Indicator Average Differences

\begin{tabular}{|l|c|c|c|}
\hline Ratios & Averages & Before Crisis & After Crisis \\
\hline Capital Adequacy Ratio & Average Deposit & 0.226 & 0.172 \\
\cline { 2 - 4 } & Average Participation & 0.150 & 0.148 \\
\cline { 2 - 4 } & Test Statistic & $3.682(0.003)$ & $2.758(0.025)$ \\
\hline \multirow{2}{*}{ Profitability 1 Ratio } & Average Deposit & 0.018 & 0.0198 \\
\cline { 2 - 4 } & Average & & \\
& & 0.026 & 0.0194 \\
\hline
\end{tabular}




\begin{tabular}{|c|c|c|c|}
\hline & Test Statistic & $-3.39(0.0058)$ & $0.132(0.449)$ \\
\hline \multirow[t]{3}{*}{ Profitability 2 Ratio } & Average Deposit & 0.156 & 0.171 \\
\hline & Average $_{\text {Participation }}$ & 0.245 & 0.15 \\
\hline & Test Statistic & $-4.086(0.002)$ & $1.487(0.09)$ \\
\hline \multirow[t]{3}{*}{ Profitability 3 Ratio } & Average Deposit & 0.409 & 0.514 \\
\hline & Average $_{\text {Participation }}$ & 0.397 & 0.254 \\
\hline & Test Statistic & $0.167(0.436)$ & $5.627(0.005)$ \\
\hline \multirow[t]{3}{*}{ Efficiency 1 Ratio } & Average Deposit & 0.5442 & 0.817 \\
\hline & Average $_{\text {Participation }}$ & 0.852 & 0.931 \\
\hline & Test Statistic & $-3.594(0.004)$ & $-2.224(0.045)$ \\
\hline \multirow[t]{3}{*}{ Efficiency 2 Ratio } & Average Deposit & 0.64 & 1.114 \\
\hline & Average $_{\text {Participation }}$ & 1.513 & 1.664 \\
\hline & Test Statistic & $-8.713(0.0001)$ & $-6.641(0.0002)$ \\
\hline \multirow[t]{3}{*}{ Efficiency 3 Ratio } & Average Deposit & 1.828 & 0.936 \\
\hline & Average $_{\text {Participation }}$ & 0.857 & 0.798 \\
\hline & Test Statistic & $1.926(0.047)$ & $3.06(0.011)$ \\
\hline \multirow[t]{3}{*}{ Liquidity 1 Ratio } & Average Deposit & 0.003 & 0.002 \\
\hline & Average $_{\text {Participation }}$ & 0.001 & 0.001 \\
\hline & Test Statistic & $13.159(0.0000)$ & $20.256(0.0000)$ \\
\hline Liquidity 2 Ratio & Average Deposit & 0.829 & 0.905 \\
\hline
\end{tabular}




\begin{tabular}{|l|c|c|c|}
\hline \multirow{4}{*}{ Leverage Ratio } & Average Participation & 0.984 & 1.021 \\
\cline { 2 - 4 } & Test Statistic & $-3.029(0.009)$ & $-3.962(0.008)$ \\
\hline & Average Deposit & 0.121 & 0.114 \\
\cline { 2 - 4 } & Average ${ }_{\text {Participation }}$ & 0.1102 & 0.128 \\
\cline { 2 - 4 } & Test Statistic & $1.3402(0.111)$ & $-1.571(0.083)$ \\
\hline
\end{tabular}

\section{Conclusion And Recommendations}

Participation banks offering interest-free banking services actively have been rising steadily since 2005. Use of money as the main dynamic of macro and micro economies in 'real' transactional activities' enhances its effectiveness and profitability in the system. 'Transformation function', which is difficult to actualize if it remains in the hands of saving holders, is gained by the economy through investors. Nevertheless, since the banking system is one of the most affected areas by the economic and financial crises it is inevitable that depositors and credit users will be in loss. This situation necessitates participation banks in order to render the system competitive, transparent, strong, dynamic and sustainable with different institutions and products. This study investigated the differences between interestfree banking and conventional banking with regard to their attitudes towards their customers (especially during crisis periods) and analyzed their different attitudes in credit loaning and whether they can be alternatives.

For this reason, capital adequacy, profitability, efficiency, liquidity and leverage ratios derived from financial charts of the banks based on two different types of operation principles have been analyzed. According to analysis results:

- It has been found out that capital adequacy ratio was not higher for participation banks than it was for the deposit banks during both periods.

- The comparison of profitability (1 and 2) ratios has shown that in the pre-crisis period, participation banks had a higher average while in the post-crisis period, the ratios were higher for deposit banks. For profitability ratio 3, the 'net profit/ paid capital' ratio, however, the situation was the opposite. After the crisis, participation banks made higher profit ratio. 
- The analysis of efficiency ratio as the main determinant of the attitudes of banks towards their customers has shown that this ratio was higher for participation banks than it was for deposit banks both during the pre- and post-crisis periods. The ratios discussed in the study were 'Loans / Deposits',' Credit Interest (dividend) Income / Deposits Interest (dividend) Expense and the ratio of Deposit Interest (dividend) + Personnel Expense Expense) / Credit interest (dividend) income as an indicator of operating expenses.

- Moreover, securities portfolio, which is essentially the concern of only deposit banks', was determined as an important efficiency ratio in terms of both customer preference and the income it provides. As securities portfolio income became more insignificant due to reduced borrowing requirements of the public sector, conventional banks have started to operate in an action-oriented manner opening credit channels for small and medium-sized enterprises (SMEs).

- Another ratio group is the liquidity ratios. According to the results, both before and after the crisis the liquidity 2 average ratio for Participation Banks was higher than Savings Banks and the results for liquidity 1 were opposite.

- Finally, while the leverage ratio for was higher for deposit banks before the crisis, after the crisis average of Participation Banks was found to be higher.

Although the share of Participation Banks in the the banking sector in Turkey is low and their history is not long, it has been found that they relatively brought more resources to the real economy than deposit banks. The majority of participation banks provide significant financing in commercial and industrial areas of SME's.

It has been identified that, apart from customer preferences, banks have differences in their attitudes during crisis periods. In the post-crisis period, as shown in deposit banks Activity 3 ratio, deposit banks had problems in deriving revenue from main operations and derived net revenue from the non-operating gains (such as portfolio interest income on marketable securities and other banking services and commission income). However, in the pre-crisis and post-crisis periods, participation banks went beyond the critical threshold in terms of strength and durability with their high rates of 'Loan/Deposit Ratio'. Project-based selectivity is an important element in the evaluation of the collected funds. In addition, in a system functioning on faith and trust, 'profit-loss sharing' is regarded another element of this strength and durability. 


\section{References}

ABDU---RAHMAN, Y. The Art of Íslamic Banking and Finance. New Jersey: John Wiley \& Sons, Inc., Hoboken, 2010.

AFŞAR, M. "Küresel Kriz ve Türk Bankacılık Sektörüne Yansımaları" Eskişehir Osmangazi Üniversitesi İ̈BF Dergisi 6(2) (2011): 143---173.

AKHAN, A. Katılım Bankaları ile Mevduat Bankaları'nın Müşteri Odaklılıklarının Karşılaştırılması, Afyonkarahisar: Afyon Kocatepe Üniversitesi Sosyal Bilimler Enstitüsü, Yayınlanmamış Tezsiz Yüksek Lisans Dönem Projesi, 2010.

AKTEPE, İ. E. Katılım Bankaları Hakkında 120 Soru---Cevap. İstanbul: Yayınlanmamıs Ders Notu, 2012.

ALANTAR, D. "Küresel Finansal Kriz: Nedenleri ve Sonuçları Üzerine Bir Değerlendirme.” Maliye

Finans Yazlar1, 81 (2008).

ATASOY, H. Türk Bankacılık Sektöründe Gelir---Gider Analizi ve Karlılık Performansının Belirleyicileri, Ankara: Türkiye Cumhuriyeti Merkez Bankası Uzmanlık Yeterlilik Tezi, 2007

BİLIR, A. Katılım Bankalarında Müşteri Memnuniyetinin Belirlenmesi Üzerine Bir Araştırma. Adana: Çukurova Üniversitesi, Sosyal Bilimler Enstitüsü, 2010.

CANBAZ, M. Katılım Bankacılığı ve Türkiye'deki Gelişimi.” Feridun Kaya (Ed.), İstanbul: in Bankacılık: Giriş ve İkeler, Beta Yayıncılık, 2012.

CANDEMİR, G. “Türk Bankacılık Sektöründe Faiz Oranı Riski Algısı ve Yönetim”, Maliye Finans Yazıları 93(2011). COŞKUN, A. Katılım Bankalarının Bankacılık Sektöründeki Yeri ve Önemi İstanbul: İstanbul Üniversitesi, Sosyal Bilimler Enstitüsü Yüksek Lisans Tezi, 2008.

DJENNAS, M., BENBOUZİANE, M, DJENNAS, M., "Currency---Banking Crises and Economic Downturns: A Comparison Between Islamic and Conventional Banks", 8th International Conference on Islamic Economics and Finance, December 19---21, Qatar, 2011.

DOĞAN, S. Katılım Bankaları ve Ekonomiye Etkileri: Türkiye Örneği. Kahramanmaraş: Kahramanma raş Sütçü İmam Üniversitesi Sosyal Bilimler Enstitüsü, Yüksek Lisans Tezi, 2008.

DOĞRU, H. "Basel II ve IAS 39 Muhasebe Standardı Çerçevesinde Menkul Kıymetleştirme İşleminin Türkiye'de Banka ve Diğer Kaynak Şirketlerin Bilanço ve Sermaye Yeterliliği Yükümlülüklerine Etkileri." Bankacilar Dergisi, 62 (2007):44---58.

ECE, N. "Dünya'da ve Türk Bankacılık Sektöründe İslam Bankaların ın Gelişimi." Akademik Bakış Dergisi 25 (2011)

ERSOY, H. "Bankacılık Krizlerin in Yönetimi." Maliye Finans Yazıları, Say1: 94 (2012).

ERSOY, H. "Türk Bankacılık Sisteminde Sermaye Yeterliliği Ve Basel Standartları" İstanbul Aydın Üniversitesi Sosyal Bilimler Dergisi, cilt. 1 (9) (2011): 53---72.

MCDONALD, J. H. Handbook Of Biological Statistics. Baltimore: Sparky House Publishing, 2009.

ÖZDEMİR, A. F. Anova Methods For The Group Means With Unknown Variances. İzmir: Dokuz Eylü1 Üniversitesi, Fen Bilimleri Enstitüsü, Doktora Tezi, 2006.

ÖZULUCAN, A. and DERAN, A. "Katılım Bankacılığı ile Geleneksel Bankaların Bankacılık Hizmetleri ve Muhasebe Uygulamaları Açısından Karşılaştırılmas 1”, Mustafa Kemal Üniversitesi, Sosyal Bilimler Enstitüsü Dergisi 6 (11) (2009): 85---108.

PARASHAR, S. P. and VENKATESH, J. "How did Islamic Banks do During Global Financial Crisis?" Banks and Bank Systems 5 (2010): 54---61.

PARLAKKAYA, R. and ÇÜRÜK, S.A. "Finansal Rasyoların Katılım Bankaları ve Geleneksel Bankalar Arasında Bir Tasnif Aracı Olarak Kullanımı: Türkiye Örneği”, Ege Akademik Bakış 11 (3) (2011): 397---405.

ŞENESEN, Ü. İşletme ve İktisat İçin Istatistik. İstanbul: Literatür Yayıncılık, 2010..

WELCH, B. L. "On the Comparison of Several Mean Values: An Alternative Approach." Biometrika 38 (3/4), (1951): 330---336. 
Business \& Management Studies: An International Journal Vol:3 Issue:1 Year:2015

YILDIRAN, M. (2011), "Küresel Finans Krizi Sürecinde Farklı Finans Uygulamalarının Analizi: Konvansiyonel ve Faizsiz Finans Sistemlerin Karşılaştırması” Bütçe Dünyası Dergisi 35 (2011): 105-120 .

YILMAZ, O. N. (2010), “ Faizsiz Bankacılık İlkeleri ve Katılım Bankacılığı.” 2010 < www.tkbb.org.tr>, 03.04 .2012 . 
BDDK (2011), “Bankacılık Düzenleme ve Denetleme Kurumu Kitapçığı” Ankara: April 2011 <http://www.wto.org/english/news e/pres11 e/pr628 e.pdf >, 15/05/2012

BDDK, Türk Bankacılık Sektörü Genel Görünümü---Aralık 2012, 2013 